\title{
Sequential injection mode of high-salinity/low-salinity water in sandstone reservoirs: oil recovery and surface reactivity tests
}

\author{
Hasan N. Al-Saedi ${ }^{1}$. Ali K. Alhuraishawy ${ }^{1} \cdot$ Ralph Flori $^{1} \cdot$ Patrick V. Brady ${ }^{2}$
}

Received: 2 November 2017 / Accepted: 4 April 2018 / Published online: 16 April 2018

(c) The Author(s) 2018

\begin{abstract}
The aim of this paper is to quantify the effect of low-salinity (LS) water on oil recovery from sandstone cores at different temperatures and at various permeabilities, oil viscosities, and $\mathrm{Ca}^{2+}$ concentrations in the formation water. Six sandstone cores were waterflooded with high-salinity (HS) and LS water at various temperatures ranging from 25 to $90{ }^{\circ} \mathrm{C}$. Four cores were allocated to oil recovery experiments, and the other two were dedicated to surface reactivity tests. The $S_{\mathrm{wi}}$ and $S_{\text {or }}$ of the cores were established, and then the cores were pre-aged for 3 days at $70{ }^{\circ} \mathrm{C}$ with oil in a closed container. We examined the effect of different ionic solutions (HS water, LS water, and double $\mathrm{Ca}^{2+} \mathrm{HS}$ water) at different temperatures. The surface reactivity test cores were flooded with the same HS and LS brines that were used in oil recovery forced-imbibition experiments. During flooding, samples of the effluent were analyzed for $\mathrm{pH}$ and $\mathrm{Ca}^{2+}$. The absence of an oil phase enabled us to isolate and quantify the important water-rock reactions. $\mathrm{Ca}^{2+}$ desorption from the core that was aged in the double $\mathrm{Ca}^{2+}$ concentration was larger than that desorbed from the other core, but $\mathrm{pH}$ and pressure was less than the other core during surface reactivity tests. Due to dehydration at high temperatures, the desorption of $\mathrm{Ca}^{2+}$ decreased as the temperature increased. Also, as the temperature increased, the $\mathrm{pH}$ gradient between the HS and LS water effluents decreased. Oil recovery forcedimbibition experiments with a double $\mathrm{Ca}^{2+}$ concentration showed a small LS water effect at all temperatures, meaning that the cores became more water-wet; however, the LS water effect was much greater when the amount of $\mathrm{Ca}^{2+}$ in the HS water was decreased by half. Furthermore, as the core permeability and oil viscosity increased, our tests showed a greater positive effect from the LS water. This work attempts to isolate the separate effects and thus examines the oil recovery achieved with the most important LS waterflood factors, which are temperature, ion exchange, and $\mathrm{pH}$.
\end{abstract}

Keywords Low salinity water flooding $\cdot$ Surface reactivity test $\cdot$ Enhanced oil recovery $\cdot$ Geochemistry $\cdot$ Cation adsorption

\section{Introduction}

The recent drop in oil prices has turned the oil industry to the cheapest improved oil recovery (IOR) techniques, such as low-salinity (LS) waterflooding. Also, the main incentives of low-salinity water flooding (LS water) are the environment-friendly EOR method, which also helps to avoid the reduction in the reservoirs' energy. That LS water requires decreasing only its salinity and the active divalent cations $\mathrm{Ca}^{2+}$ and $\mathrm{Mg}^{2+}$ make LS waterflooding the cheapest IOR technique.

Hasan N. Al-Saedi

hnav36@mst.edu

1 Missouri University of Science and Technology, Rolla, USA

2 Sandia National Laboratories, Albuquerque, USA
Waterflooding is extensively applied worldwide to improve oil recovery. It is documented that water chemistry significantly impacts the oil recovery factor (Morrow and Buckley 2011). In the past few years, many researchers have reported that the waterflooding recovery factor increased significantly by injecting high-salinity (HS) brine (seawater) into carbonate reservoirs (Strand et al. 2008; Shariatpanahi et al. 2010) and low-salinity brine into sandstone reservoirs (RezaeiDoust et al. 2011). Wettability is one of the major parameters that control the efficiency of waterflooding. The wettability of a rock surface is determined by the thickness and stability of the water film between the rock surface and the crude oil (Fathi et al. 2011).

The wettability alteration mechanisms during low-salinity waterflooding are even less understood than the highsalinity injection in sandstone reservoirs. Several possible proposed mechanisms include (1) multicomponent ion 
exchange (Lager et al. 2008a, b), (2) double-layer expansion (Ligthelm et al. 2009), (3) reduction in interfacial tension and increased $\mathrm{pH}$ (McGuire et al. 2005), (4) fines mobilization (Tang and Morrow 1999), (5) mineral dissolution (Aksulu et al. 2012), (6) organic material desorption from the clay surface (Austad et al. 2010), (7) salt-in effect (RezaeiDoust et al. 2009). However, the presence of clays in the porous media has proven to greatly impact production (Tang and Morrow 1999; Lager et al. 2008a, b). In addition, the chemical composition of the injected water has proved to be another controlling parameter (RezaeiDoust et al. 2009, 2011; Austad et al. 2010). The control of mineralogy and water chemistry in oil recovery highlight the importance of considering simultaneous water-rock interactions, including mineral dissolution, desorption, and ion exchange during the low-salinity waterflooding of sandstone rocks. On the other hand, increasing the oil viscosity also makes residual oil saturation higher (Aboujafar 2014). To our knowledge, no experimental studies have been conducted that consider the impact of the permeability on LS waterflooding. Mineral compositions, formation water salinity, and temperature significantly influence the wettability alteration while flooding by low-salinity water in sandstone (Aghaeifar et al. 2015). Aghaeifar et al. (2015) found that when the formation water salinity was as high as $200,000 \mathrm{ppm}$ at $100{ }^{\circ} \mathrm{C}$, no LS water effect on oil recovery was observed. However, the LS water effect was significant when the formation water salinity was reduced to $23,000 \mathrm{ppm}$. On the other hand, incremental oil recovery was ascribed to the decreasing injection water salinity. Alhuraishawy et al. (2016) examined several LS water salinities $(1,0.1$, and $0.01 \% \mathrm{NaCl})$, which produced oil recovery of 34,40 , and $45 \%$, respectively.

Brady et al. (2015) classify the pH during LS flooding and the effect of low-salinity waterflooding into three categories: (1) $\mathrm{pH}<5$, because the low positive charge of oil to kaolinite means that the LSW can weaken oil's affinity toward kaolinite; (2) pH 5-6, which is the strongest LS water effect due to the ability of LS water to convert the interactional forces to cause repulsion between oil and kaolinite. (3) $\mathrm{pH}>6$, because at all salinities the repulsion forces switch to the interactions forces.

When LS water displaces $\mathrm{HS}$ water $\mathrm{Ca}^{2+}$ desorbed from the clay surface because an ion exchange $\left(\mathrm{H}^{+}\right.$substitutes $\mathrm{Ca}^{2+}$ ) at the negative sites of the clay surface (Eq. 1); Then, organic materials will be desorbed from the clay due to the reaction between the protonated basic and adsorbed acidic materials with $\mathrm{OH}^{-}$(Eqs. 2, 3) (Austad et al. 2010).

$$
\text { Clay }-\mathrm{Ca}^{2+}+\mathrm{H}_{2} \mathrm{O} \leftrightarrow \text { clay }-\mathrm{H}^{+}+\mathrm{Ca}^{2+}+\mathrm{OH}^{-}+\text {heat }
$$

$$
\text { Clay }-\mathrm{R}_{3} \mathrm{NH}^{+}+\mathrm{OH}^{-} \leftrightarrow \text { clay }+\mathrm{R}_{3} \mathrm{~N}:+\mathrm{H}_{2} \mathrm{O}
$$

clay- $\mathrm{RCOOH}+\mathrm{OH}^{-} \leftrightarrow$ clay $+\mathrm{RCOO}^{-}+\mathrm{H}_{2} \mathrm{O}$
Six outcrop cores were used in this paper, four for oil recovery and two for surface reactivity tests. This work aims to answer the following questions:

(1) Can the varying $\mathrm{Ca}^{2+}$ concentration in formation water affect the LS water-enhanced oil recovery (EOR) mechanism(s)?

(2) Can different permeabilities affect oil recovery by LS waterflooding?

(3) Would the oil recovery be the same with different oil viscosities?

(4) Would the different $\mathrm{Ca}^{2+}$ concentrations in the formation water affect the desorption of $\mathrm{Ca}^{2+}$ during LS waterflooding?

(5) Is temperature an important factor in relation to all the above questions?

\section{Methodology}

\section{Materials}

Three brines were prepared for all experiments (Table 1). Two kind of synthetic oil were used, the viscosities were 37 and $190 \mathrm{cp}$ oil. Outcrop Berea sandstone was sampled (2.54 diameter) from $12^{\prime \prime} \times 12^{\prime \prime} \times 12^{\prime \prime}$ core samples. The core dimensions and properties are delineated in Table 2.

\section{Setup}

The simple model made of sandstone cores and a core holder was built to study the effect of key parameters on oil recovery, brine concentration, oil viscosity, permeability, and temperature. Schematics of the model used in these experiments are presented in Fig. 1. This model includes a core holder, an accumulator, a syringe pump, and a deionized (DI) water source.

Table 1 Composition of brines (mol/L)

\begin{tabular}{lccl}
\hline Element & HS & HS* & LS \\
\hline $\mathrm{Na}^{+}$ & 1.50 & 1.34 & 0.0167 \\
$\mathrm{Cl}^{-}$ & 1.65 & 1.69 & 0.0165 \\
$\mathrm{Ca}^{2+}$ & 0.089 & 0.178 & 0 \\
$\mathrm{TDS}(\mathrm{g} / \mathrm{l})$ & 98.32 & 98.32 & 1.182 \\
Salinity (ppm) & 98,320 & 98,320 & 1182 \\
$\mathrm{IS}$ & 1.75 & 1.87 & 0.0166 \\
$\mathrm{pH}$ & 7.20 & 7.22 & 7.04 \\
\hline
\end{tabular}

TDS Total dissolved solids; IS Ionic Strength
吾

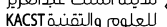


Table 2 Mineralogy core properties

\begin{tabular}{lllllll}
\hline Core & Quartz $(\%)$ & Kaolinite $(\%)$ & Diameter $(\mathrm{cm})$ & Length $(\mathrm{cm})$ & $\mathrm{K}(\mathrm{md})$ & Porosity $(\%)$ \\
\hline Core\#1 & \multirow{2}{*}{95} & 5 & 2.54 & 14.80 & $\sim 100$ & $\sim 23$ \\
Core\#2 & & & 2.54 & 14.82 & & \\
Core\#3 & & 2.54 & 14.99 & & \\
SRT\#1 & & 2.54 & 14.89 & & \\
SRT\#2 & & 2.54 & 14.92 & & \\
Core\#4 & 93 & 7 & 2.54 & 14.70 & 253 & 23.25 \\
\hline
\end{tabular}

Fig. 1 Schematic diagram of the experimental apparatus

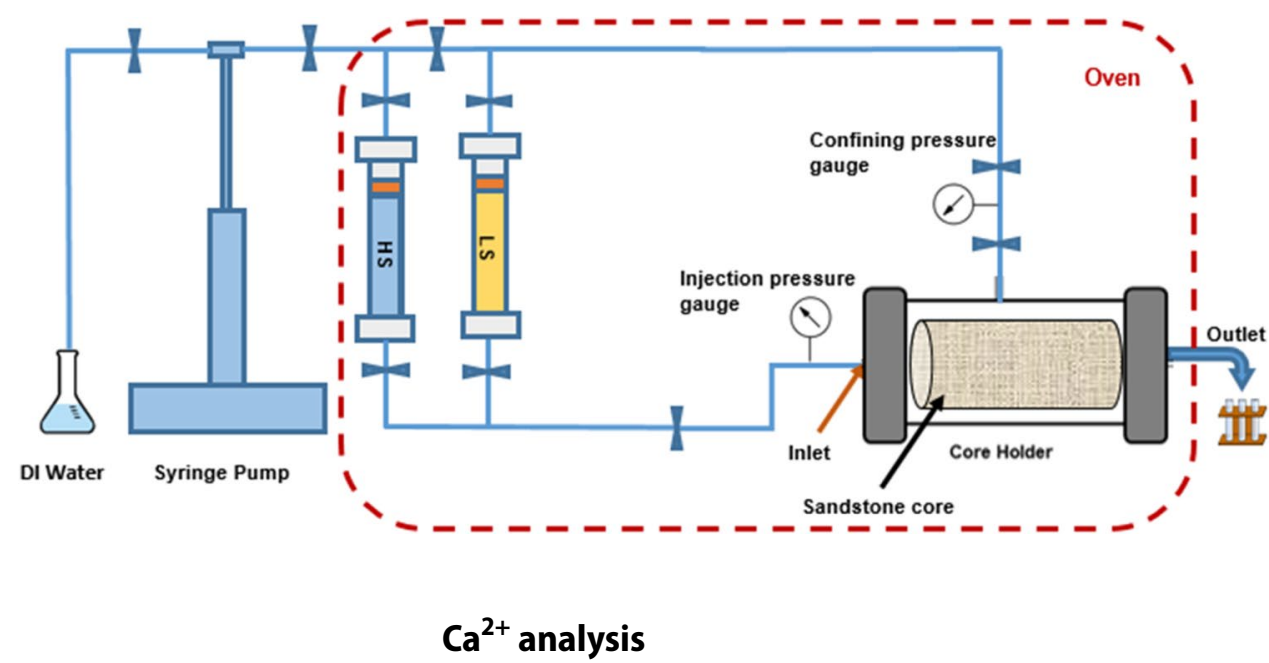

The concentrations of $\mathrm{Ca}^{+2}$ were measured by inductively coupled plasma-optical emission spectrometry using a PerkinElmer ${ }^{\circledR}$ 2000D ICP-OES. The samples were diluted in a $2 \%$ HN03 solution. QC 5PPM was run between and at the end of the samples to check the instrument performance and also to spike the sample; the spike recovery was $97 \%$.

\section{Results}

The cores were pre-aged in oil at $80^{\circ} \mathrm{C}$ for 2 weeks. In all experiments, HS water was injected into the core at $25^{\circ} \mathrm{C}$. When no more oil was produced and the stable pressure dropped across the core, the injected fluid was switched to LS water at the same temperature until no incremental oil recovery was obtained with a constant pressure drop. While the injected fluid remained the same, the temperature was increased to $70{ }^{\circ} \mathrm{C}$ until the same conditions mentioned previously were observed. Finally, the temperature was raised to $90{ }^{\circ} \mathrm{C}$ with the same LS water until a stable pressure drop occurred across the core, and no oil recovery was observed. The oil viscosity was the same for core\#1, core\#3, and core\#4, but not for core\#2. Core\#2 had a higher viscosity than the others to study the effect of the oil viscosity on the oil recovery by LS waterflooding. and $90{ }^{\circ} \mathrm{C}$ until the pH stabilized. The effluent samples were collected using a fraction collector $(2-3 \mathrm{ml})$ for $\mathrm{Ca}^{2+}$ analyses and $\mathrm{pH}$ measurements. 


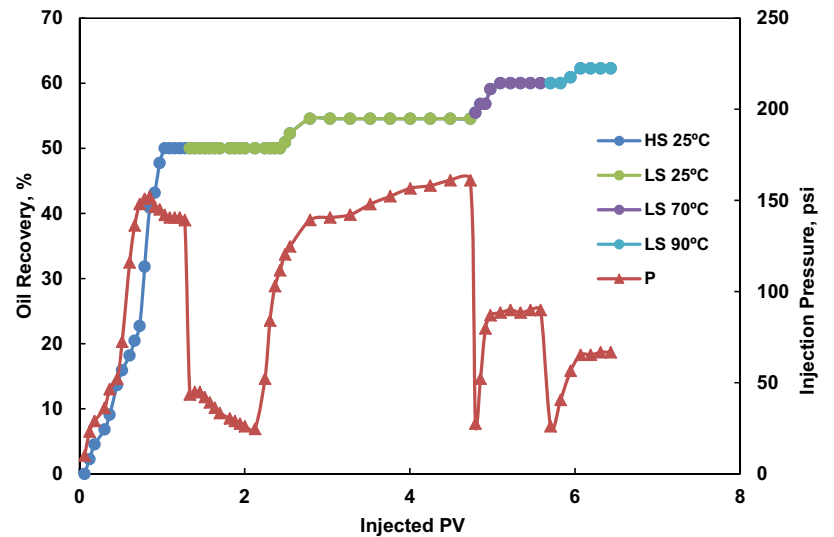

Fig. 2 Oil recovery factor and pressure profile for core\#1, which was sequentially flooded by $\mathrm{HS}$ water/LS water at 25,70 , and $90{ }^{\circ} \mathrm{C}$

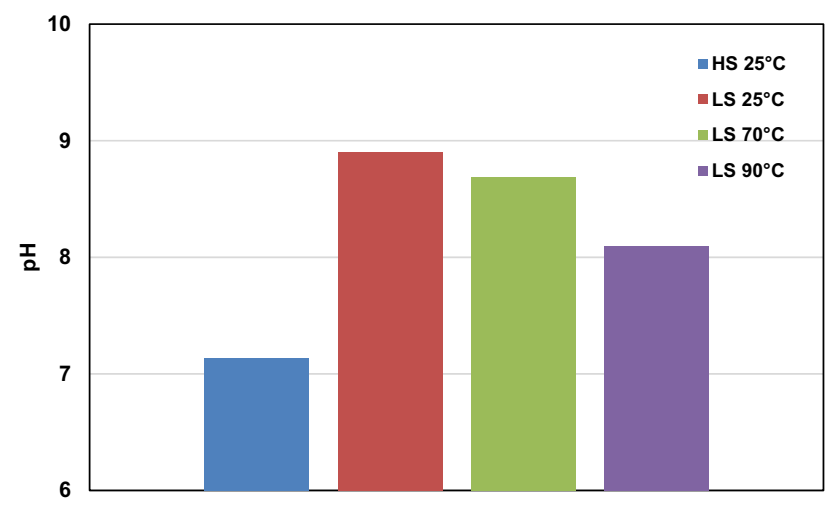

Fig. 3 Effluent $\mathrm{pH}$ profile at 25,70 , and $90{ }^{\circ} \mathrm{C}$ for core\#1

\section{Effect of temperature on oil recovery by LS water, core\#1}

The same aging HS water of $\sim 100,000 \mathrm{ppm}$ (containing $89 \mu \mu \mathrm{Ca}^{2+}$ ) was injected into the core at $25^{\circ} \mathrm{C}$. More ultimate oil recovery was observed with increasing temperature (Fig. 2). The oil recovery from HS waterflooding was $50 \%$ OOIP. When LS water [containing zero Millimole ( $\mu$ mole) $\mathrm{Ca}^{2+}$ ] was then injected into the core at the same temperature, the oil recovery factor increased by $4.55 \%$. When the same LS water was injected into the core at $70{ }^{\circ} \mathrm{C}$, oil recovery increased significantly, by $5.45 \%$ OOIP. There was also an increase in the oil recovery of about $2.27 \%$ when the temperature changed to $90{ }^{\circ} \mathrm{C}$, meaning that the LS water at all temperatures combined enhanced the oil recovery by $12.27 \%$ OOIP (Fig. 2). Figure 2 shows a normal pressure trend at $25^{\circ} \mathrm{C}$ for both HS and LS water and at 70 and $90{ }^{\circ} \mathrm{C}$ for LS water. The $\mathrm{pH}$ was 7.14 while flooded with HS water. Upon switching to LS water, the $\mathrm{pH}$ rose to 8.9 at the same temperature and then began to decrease to 8.69 and 8.1 , at 70 and $90{ }^{\circ} \mathrm{C}$,

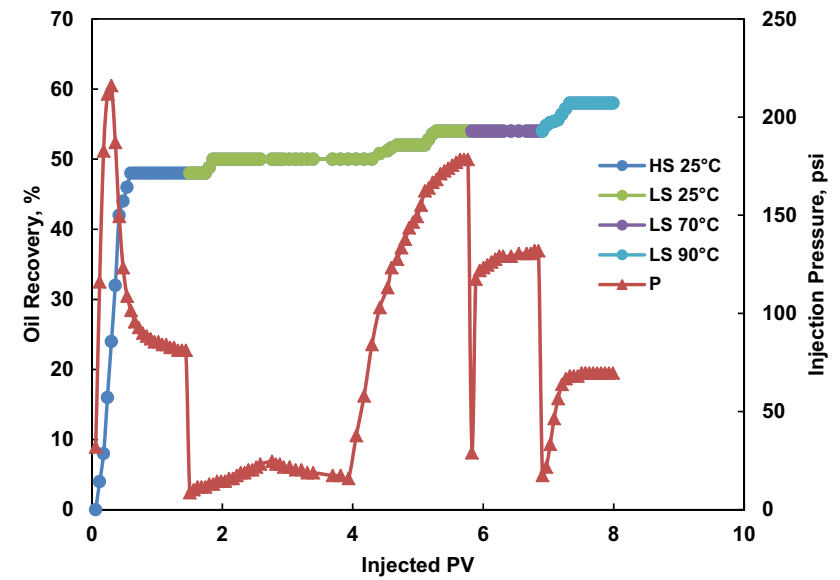

Fig. 4 Oil recovery factor and pressure profile for core\#2, which was sequentially flooded by HS water-LS water at 25,70 , and $90{ }^{\circ} \mathrm{C}$

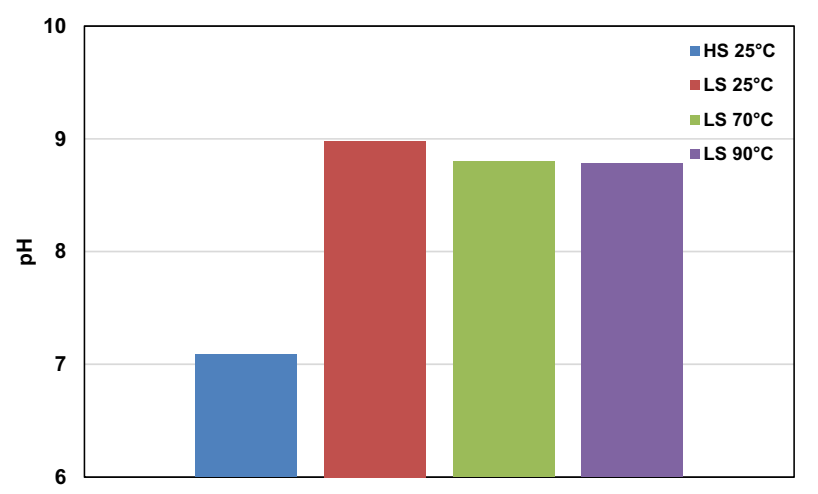

Fig. 5 Effluent $\mathrm{pH}$ profile at 25,70 , and $90{ }^{\circ} \mathrm{C}$ for core\#2

respectively. The trend related to changes in the $\mathrm{pH}$ for the LS effluent is clearly a function of temperature (Fig. 3).

\section{Effect of oil viscosity and temperature on oil recovery by LS water, core\#2}

The oil viscosity used for this core was higher than the oil viscosity in core\#1. The ultimate oil recovery for this core from HS waterflooding was $48 \%$ OOIP at $25{ }^{\circ} \mathrm{C}$. This was lower than the value for core\#1, which was $50 \%$ OOIP at the same temperature. Upon switching to LS water, the ultimate oil recovery jumped by $6 \%$ OOIP at $25^{\circ} \mathrm{C}$. At $70{ }^{\circ} \mathrm{C}$, there was no oil recovery by the same LS water, while at $90{ }^{\circ} \mathrm{C}$, there was about $4 \%$ OOIP. The ultimate oil recovery between HS water at $25^{\circ} \mathrm{C}$ and LS waterflooding at all temperatures (i.e., 25,70 , and $90^{\circ} \mathrm{C}$ ) was $10 \%$ compared to $12.27 \%$ for the reference core (core\#1) (Fig. 4). The injection pressure increased rapidly until the Sor was established. Figure 4 shows that as the temperature increased, the pressure decreased. The $\mathrm{pH}$ for the HS water effluent was 7.09. The water was then switched to 


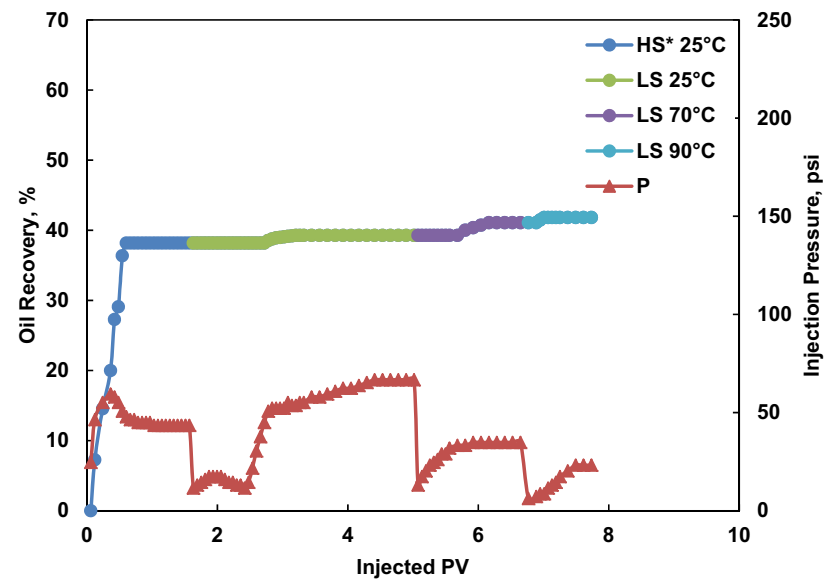

Fig. 6 Oil recovery factor and pressure profile for core\#3, which was sequentially flooded by HS water/LS water at 25,70 , and $90{ }^{\circ} \mathrm{C}$

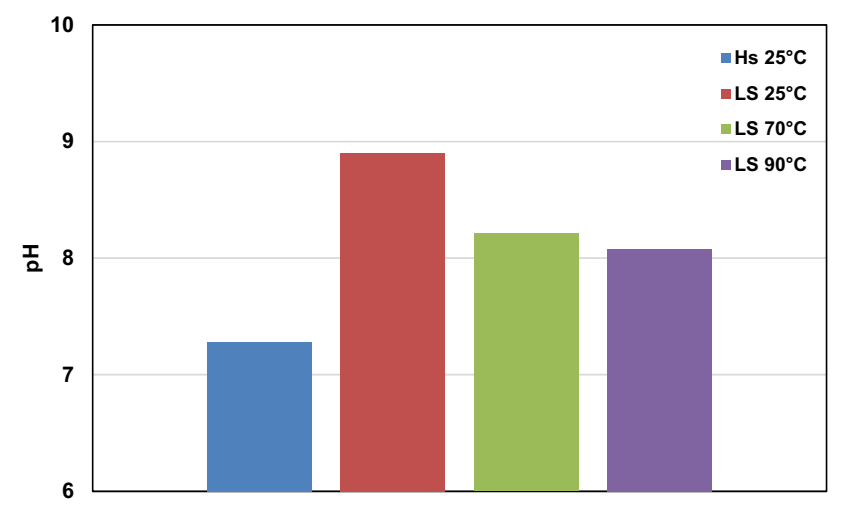

Fig. 7 Effluent $\mathrm{pH}$ profile at 25,70 , and $90{ }^{\circ} \mathrm{C}$ for (core\#3)

the LS water; the $\mathrm{pH}$ for the LS water effluent was $~ 9.0$. Next, changing the temperature to either 70 or $90{ }^{\circ} \mathrm{C}$ stabilized the pH at 8.8 and 8.5, respectively (Fig. 5).

\section{Effect of $\mathrm{Ca}^{2+}$ concentration and temperature on oil recovery by LS water, core\#3}

The concentration of $\mathrm{Ca}^{2+}$ was doubled in the aging water $\left(\mathrm{HS}^{*}\right)$ for this core. Each core was aged in $89 \mu$ mole, except this core, which used $178 \mu \mathrm{mol}$ to investigate the role of the potential determining ion toward sandstone which is $\mathrm{Ca}^{2+}$. The same $\mathrm{HS}^{*}$ water was used for flooding in the oil recovery test. The ultimate oil recovery was less than that observed in core\#1, which was itself lower than from core\#2. Core\#3 was retrieved from the same Berea sandstone. The ultimate oil recovery was about $38.2 \%$

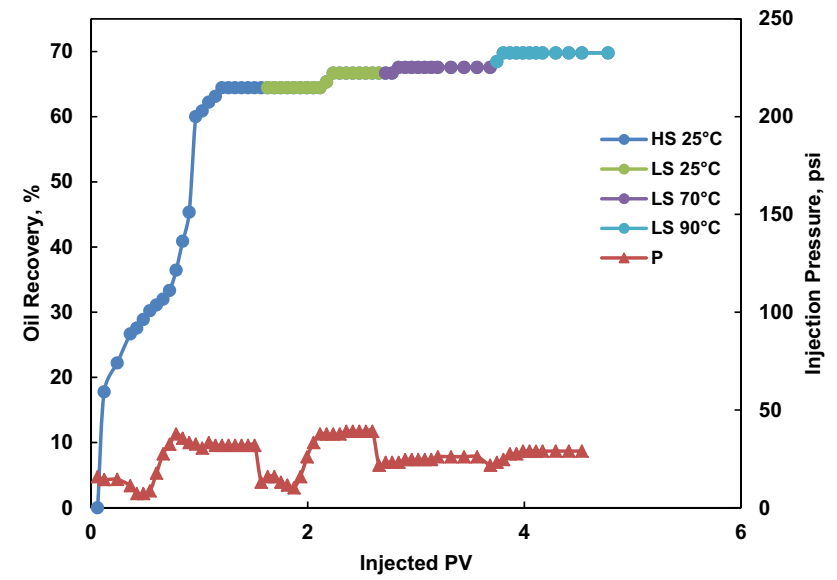

Fig. 8 Oil recovery factor and pressure profile for core\#4, which was sequentially flooded by HS water-LS water at 25,70 , and $90{ }^{\circ} \mathrm{C}$

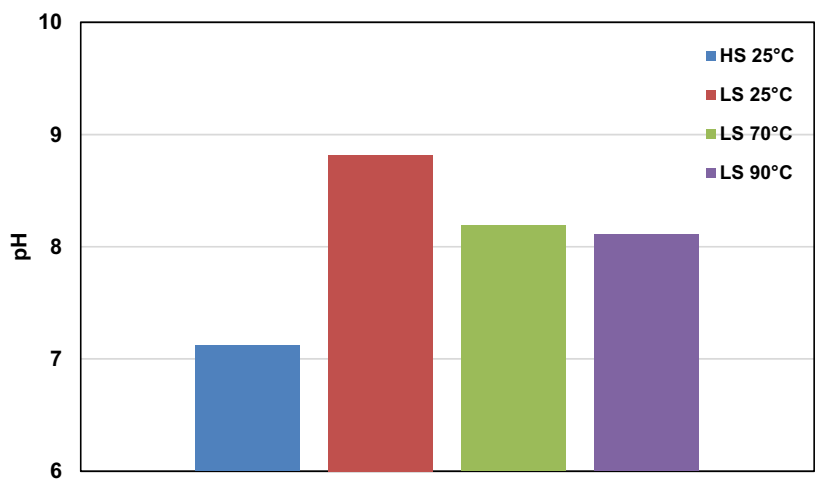

Fig. 9 Effluent $\mathrm{pH}$ profile at 25,70 , and $90{ }^{\circ} \mathrm{C}$ for core\#4

OOIP, after the core was flooded with $\mathrm{HS}^{*}$ water at $25^{\circ} \mathrm{C}$. Upon switching the injected brine to LS water, the incremental oil recovery was $1.09,1.82 \%$, and 0.73 at 25,70 , and $90{ }^{\circ} \mathrm{C}$, respectively (Fig. 6). As pointed out in the Core\#1, the $\mathrm{pH}$ jumped during LS water flooding. As the temperature increased, the LS water effluent $\mathrm{pH}$ tended to decrease (Fig. 7). The injection pressure proportioned inversely with temperature. However, the injected pressure did not rise as much as in the core\#1 run (Fig. 6).

\section{Effect of permeability and temperature on oil recovery by LS water, core\#4}

To investigate the permeability effect on LS water EOR, this outcrop core was sampled from a higher permeability than the three previous triplet cores. Sequential waterflooding was conducted on this core in the same manner as previously described. The HS water that was injected initially provided $\sim 65 \%$ OOIP ultimate oil recovery, which was greater than that observed in core\# 1 . However, the 
opposite was observed when LS water was injected, except at $90{ }^{\circ} \mathrm{C}$. The ultimate oil recovery was $2.22,0.89$, and $2.23 \%$ OOIP at 25,70 , and $90{ }^{\circ} \mathrm{C}$, respectively (Fig. 8 ). In addition, a lowest injected pressure was recorded in this core. Figure 9 shows an important $\mathrm{pH}$ jump after switching from the HS water to LS water. We observed a strong link between temperature and $\mathrm{pH}$ : the $\mathrm{pH}$ decreased as the temperature increased. The LS water injected pressure followed the same trend.
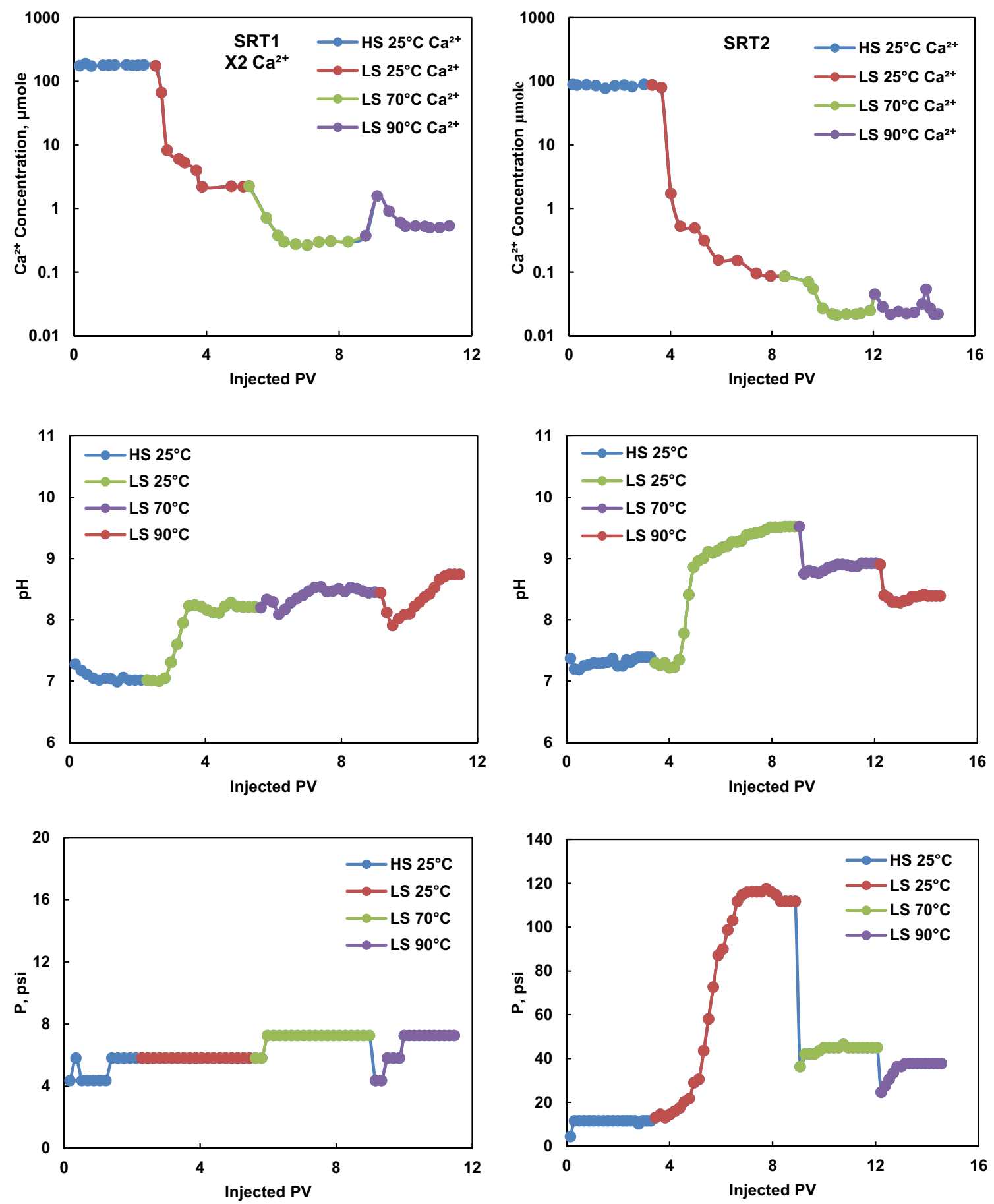

Fig. 10 Surface reactivity test analyses, SRT1 and SRT2 


\section{Surface reactivity tests (SRTs) Analyses}

SRT1 and SRT2 core samples were taken close together and from the same zone as the triplet cores used in the oil recovery test.

\section{SRT1 and SRT2}

Figure $10 \mathrm{a}, \mathrm{d}$ shows the effluent $\mathrm{Ca}^{2+}$ concentration, where SRT1 contains twice as much $\mathrm{Ca}^{2+}$ as SRT2. The concentration of $\mathrm{Ca}^{2+}$ during the $\mathrm{HS}$ waterflooding stabilized below $170 \mu \mathrm{mol}$ (which was slightly below the injected $\mathrm{Ca}^{2+}$ ), meaning that some of the $\mathrm{Ca}^{2+}$ linked to the kaolinite negative surface. The concentration remained the same until the injected fluid was switched to LS water. The low-salinity fluid contained no $\mathrm{Ca}^{2+}$. After the LS water invaded the core, $\mathrm{Ca}^{2+}$ desorption occurred at all temperatures; however, for SRT1, desorption does not reveal a clear trend with temperature (desorption at $90{ }^{\circ} \mathrm{C}$ greater than at $70{ }^{\circ} \mathrm{C}$ ), meaning that an ion exchange occurred between the LS water and sandstone. Quartz and kaolinite exchanged $\mathrm{H}^{+}$with $\mathrm{Ca}^{2+}$. Figure 10b, e presents the increase by $1.20 \mathrm{pH}$ units with LS waterflooding, while the $\mathrm{pH}$ rose to 2.13 in the SRT2. The pressure increase in SRT1 was not as pronounced as that in SRT2, meaning that a lower $\mathrm{Ca}^{2+}$ concentration resulted in a higher LS water efficiency (Fig. 10c, f).

\section{Discussion}

While water chemistry, temperature, oil viscosity, $\mathrm{Ca}^{2+}$ concentration, and permeability all affected the oil recovery, the $\mathrm{Ca}^{2+}$ concentration had the lowest positive impact. In contrast, temperature, oil viscosity, and permeability had the largest positive impacts. The more reservoir permeability, the more

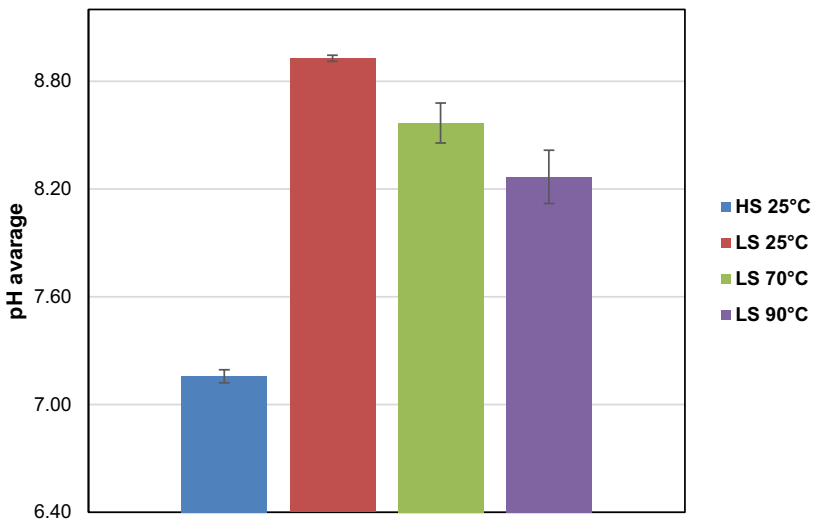

Fig. 12 Error bars for $\mathrm{pH}$ measurements

ultimate oil recovery. On the other hand, with higher $\mathrm{Ca}^{2+}$ concentrations in the formation water, there was less ultimate oil recovery. The highest impact on the $\mathrm{pH}$ was in core\#2 (Fig. 11). The $\mathrm{pH}$ jump in the LS effluent for all cores at all temperatures is attributed to the ion exchanges of $\mathrm{Ca}^{2+}$ with $\mathrm{H}^{+}$ and $\mathrm{Na}^{+}$with $\mathrm{H}^{+}$(Austad et al. 2010; Brady et al. 2015). The alkaline environment was able to alter the wettability toward being more water-wet (Eq. 1) and (Eq. 4, Wieland et al. 1994). Figure 12 shows that as the temperature rose, measurement errors increased.

$>\mathrm{Na}+\mathrm{H}^{+} \leftrightarrow>\mathrm{H}+\mathrm{Na}^{+}$

We observed a delay in the breakthrough of the early injected water between approximately $0.5-1.0$ injected pore volume, at $25{ }^{\circ} \mathrm{C}$ only; after that, the oil started to flow. One explanation is after the HS water was injected into the core, adsorption of $\mathrm{Ca}^{2+}$ occurred on the negative site of the clay because HS water contains $89 \mu \mathrm{mol}$ of $\mathrm{Ca}^{2+}$.
Fig. 11 Effluent $\mathrm{pH}$ comparison at 25,70 , and $90^{\circ} \mathrm{C}$ for cores 1 , 2,3 , and 4

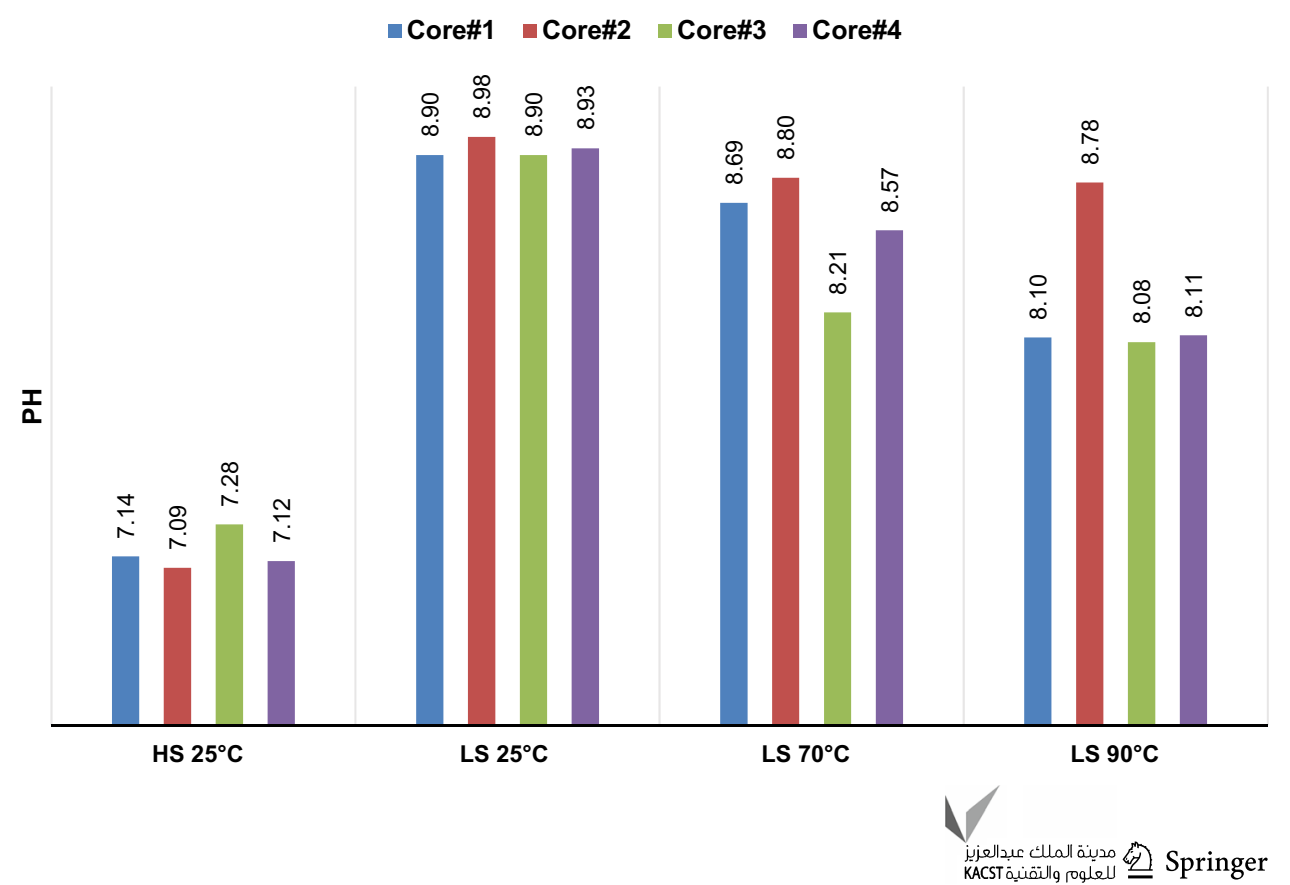


When the LS water invaded the core, the ion exchange started. Then, a higher $\mathrm{pH}$ was observed in the effluent, and the pressure rose rapidly. That promoted reservoir water-wetness, which improved the microscopic sweep efficiency. The injection pressure might have increased because after the breakthrough delay and ion exchange occurred, the LS water flows deep through the pores and that could be the reason of increasing microscopic sweep efficiency. Also, as the temperature rose, the oil viscosity decreased. That would explain the lower injected pressure during the LS at 70 and $90{ }^{\circ} \mathrm{C}$. The injected pressure in all stages for core\#4 was lower than for core\#1 and core\#2 because the microscopic sweep efficiency in core\#4 was not as pronounced as those in core\#1 and core\#2. The same pressure trend was observed in core\#3 because more water-wetness makes the injected LS water flow through the core without obstruction (Figs. 2, 4, 6, 8).

Figure 13 displays a comparison of the ultimate oil recovery for all cores at all temperatures. For HS water at $25{ }^{\circ} \mathrm{C}$, core\#4 had the highest ultimate oil recovery due to the high permeability among the other cores, which is ascribed to the higher volumetric sweep efficiency. The highest ultimate recovery from LS water at $25{ }^{\circ} \mathrm{C}$ was for core\#2, while zero ultimate oil recovery was found at $70{ }^{\circ} \mathrm{C}$ for core\#2. The largest percent of oil was recovered for core\#1 and core\#2 at 70 and $90{ }^{\circ} \mathrm{C}$, respectively. The most effective factors are detailed below, showing the rankings of the cores from best to worst:

a. HS $25^{\circ} \mathrm{C}$ : (1) core\#4, (2) core\#1, (3) core\#2, and (4) core\#3. b. LS $25^{\circ} \mathrm{C}$ : (1) core\#2, (2) core\#1, (3) core\#4, and (4) core\#3.

c. LS $70{ }^{\circ} \mathrm{C}$ : (1) core\#1, (2) core\#3, (3) core\#4, and (4) core\#2.

d. LS $90{ }^{\circ} \mathrm{C}$ : $(1)$ core $\# 2,(2)$ core\# $4 \approx$ core\# 1 , and $(3)$ core\#3.

e. Total LS: (1) core\#1, (2) core\#2, (3) core\#4, and (4) core\#3.

f. Total recovery rankings: (1) core\#4, (2) core\#1, (3) core\#2, and (4) core\#3.

Therefore, the most effective factor influencing the ultimate oil recovery in overall flooding (HS water) was permeability, as in core\#4, while temperature (only in core\#1) was the most effective for LS waterflooding. Remember that core\#2 was aged in high-viscosity oil, as the viscosity increased, the ultimate oil recovery increased in the LS water at 25 and $90{ }^{\circ} \mathrm{C}$. Related to the Core\#3 results, Aghaeifar et al. (2015) performed a systematic study of the relationship between the formation salinity and the LS EOR effect. When the formation water was used for aging and the flooding salinity was $200,000 \mathrm{ppm}(640$ ( $\mu$ mole $) \mathrm{Ca}^{2+}$ concentration), no LS EOR effect was observed because the high formation water salinity turned the initial rock wettability into strongly water-wet; however, when that water was changed to $\sim 22,000 \mathrm{ppm}\left(3.5 \mu \mathrm{mol} \mathrm{Ca}{ }^{2+}\right.$ concentration), an LS EOR effect was observed. However, when we kept the salinity at the same level ( 100,000 ppm), but the concentration of $\mathrm{Ca}^{2+}$ was doubled (from 89 to $178 \mu \mathrm{mol}$ ), more water-wetness occurred; in turn, we found a lower LS EOR effect than for the other cores because of the capillary
Fig. 13 Comparison in terms of ultimate oil recovery for all cores at 25,70 , and $90^{\circ} \mathrm{C}$

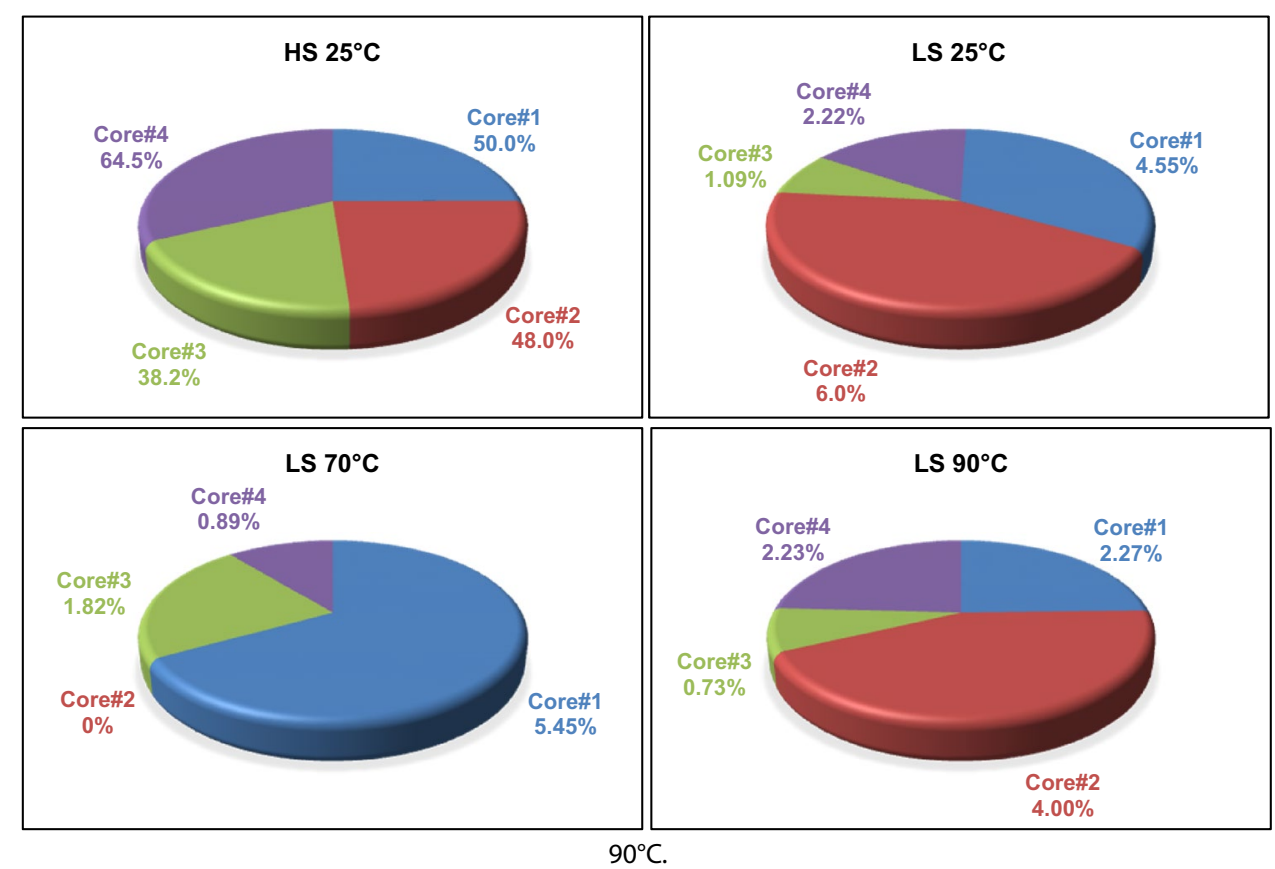


the capillary effect, because of that and for further investigations, the surface reactivity tests (SRTs) were performed. The $\mathrm{Ca}^{2+}$ desorption for SRT1 was larger than for SRT2, but SRT2 showed a clear trend with temperature. (As the temperature increased, the desorption decreased.) The ion exchange for SRT1 was greater than for SRT2, but the $\mathrm{pH}$ surge for SRT2 was larger than for SRT1. Also, the pressure was much higher for SRT2 when the LS water invaded the core, meaning that the lower the $\mathrm{Ca}^{2+}$ concentration in the formation water, the great the effect of the LS water. The increase in pressure in SRT2 indicates that LS water improved the microscopic sweep efficiency, but for SRT1, the water flowed with no obstruction. The low $\mathrm{Ca}^{2+}$ concentration in SRT2 promoted a more alkaline environment, which altered the wettability, making it more water-wet.

\section{Conclusion}

$\mathrm{Ca}^{2+}$ desorption is associated with a $\mathrm{pH}$ jump; thereby, an increase in the microscopic sweep efficiency was the key point of this work at a different temperatures. In addition, oil viscosity and permeability at various temperatures had a large impact on the LS water EOR. The following conclusions were established:

1. The $\mathrm{HS}^{*}$ water (doubled $\mathrm{Ca}^{2+}$ ) shifted the wettability toward strongly water-wet, despite the salinity being the same, which would obviously lower the ultimate oil recovery.

2. The ultimate oil recovery was observed with varying temperatures in core\#3, but the effect of temperature was not as pronounced as that of the $\mathrm{Ca}^{2+}$ concentration.

3. Higher permeability promotes volumetric sweep efficiency, thereby improving the ultimate oil recovery during secondary and tertiary oil recovery.

4. That the alkaline environment created after the LS water invaded the porous media induced the wettability to become more water-wet.

5. High oil viscosity promoted oil recovery, especially at LS $25^{\circ} \mathrm{C}$ and LS $90{ }^{\circ} \mathrm{C}$.

6. As the temperature increased, more banks of movable oil were obtained because higher temperatures reduce oil viscosity.

7. Surface reactivity tests showed that ion exchange is important for oil recovery but not essential, especially when a large amount of $\mathrm{Ca}^{2+}$ exists in the formation water.

Open Access This article is distributed under the terms of the Creative Commons Attribution 4.0 International License (http://creat ivecommons.org/licenses/by/4.0/), which permits unrestricted use, distribution, and reproduction in any medium, provided you give appropriate credit to the original author(s) and the source, provide a link to the Creative Commons license, and indicate if changes were made.

\section{References}

Aboujafar SM (2014) Effect of oil viscosity and brine salinity/viscosity on water/oil relative permeability and residual saturations. In: SPWLA 55th annual logging symposium, Abu Dhabi, 18-22 May

Aghaeifar Z, Strand S, Austad T, Puntervold T, Aksulu H, Navratil K, Storås S, Håms $\varnothing$ D (2015) Influence of formation water salinity/composition on the low-salinity enhanced oil recovery effect in high-temperature sandstone reservoirs. Energy Fuels 29(8):4747-4754

Aksulu H, Håms $\varnothing$ D, Strand S, Puntervold T, Austad T (2012) Evaluation of low-salinity enhanced oil recovery effects in sandstone: effects of the temperature and $\mathrm{pH}$ gradient. Energy Fuels 26:3497-3503

Alhuraishawy AK, Imqam A, Wei M, Bai B (2016) Coupling low salinity water flooding and preformed particle gel to enhance oil recovery for fractured carbonate reservoirs. In: SPE western regional meeting, Anchorage, Alaska, 23-26 May. SPE-180386-MS. http:// dx.doi.org/10.2118/180386-MS

Austad T, RezaeiDoust A, Puntervold T (2010) Chemical mechanism of low salinity water flooding in sandstone reservoirs. In: proceedings of the 2010 society of petroleum engineers (SPE) improved oil recovery symposium, Tulsa, Oklahoma, 24-28 April. SPE-129767

Brady PV, Morrow NR, Fogden A, Deniz V, Loahardjo NW (2015) Electrostatics and the low salinity effect in sandstone reservoirs. Energy Fuels 29(2):666-677

Fathi J, Austad T, Strand S (2011) Water-based enhanced oil recovery (EOR) by smart water: optimal ionic composition for EOR in carbonates. Energy Fuels 25(11):5173-5179

Lager A, Webb KJ, Black CJJ, Singleton M, Sorbie KS (2008a) Low salinity oil recovery - an experimental investigation. Petrophysics 49(1):28-35

Lager A, Webb KJ, Collins IR, Richmond DM (2008) LoSal enhanced oil recovery: evidence of enhanced oil recovery at the reservoir scale. In: Proceedings of the 2008 society of petroleum engineers (SPE) symposium on improved oil recovery, Tulsa, Oklahoma, 19-23 April. SPE-113976

Ligthelm DJ, Gronsveld J, Hofman JP, Brussee NJ, Marcelis F, van der Linde HA (2009) Novel waterflooding strategy by manipulation of injection brine composition. In: EUROPEC/EAGE conference and exhibition, Amsterdam, 8-11 June. SPE-119835. http://dx.doi. org/10.2118/119835-MS

McGuire PL, Chatham JR, Paskvan FK, Sommer DM, Carini FH (2005) Low salinity oil recovery: an exciting new EOR opportunity for Alaska's North Slope. In: SPE western regional meeting, Irvine, California, 30 March-1 April. http://dx.doi. org/10.2118/93903-MS

Morrow N, Buckley J (2011) Improved oil recovery by low-salinity waterflooding. J Pet Technol 63(05):106-112

RezaeiDoust A, Puntervold T, Strand S, Austad T (2009) Smart water as wettability modifier in carbonate and sandstone: a discussion of similarities/differences in the chemical mechanisms. Energy Fuels 23(9):4479-4485

RezaeiDoust A, Puntervold T, Austad T (2011) Chemical verification of the EOR mechanism by using low saline/smart water in sandstone. Energy Fuels 25:2151-2162

Shariatpanahi SF, Strand S, Austad T (2010) Evaluation of waterbased enhanced oil recovery (EOR) by wettability alteration in

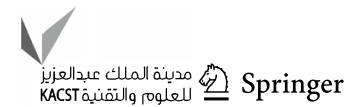


a low-permeable fractured limestone oil reservoir. Energy Fuels 24:5997-6008

Strand S, Austad T, Puntervold T, Høgnesen EJ, Olsen M, Barstad SMF (2008) "Smart water" for oil recovery from fractured limestone: a preliminary study. Energy Fuels 22:3126-3133

Tang GQ, Morrow NR (1999) Influence of brine composition and fines migration on crude oil brine rock interactions and oil recovery. $\mathrm{J}$ Pet Sci Technol 24:99-111

Wieland E, Wanner H, Albinnson Y, Wersin P, Karnland O (1994) A surface chemical model of the Bentonite-Water interface and its implications for modelling the near field chemistry in a repository for spent fuel, SKB Technical Report 94-26. Svensk Kärnbränslehantering $\mathrm{AB}$, Stockholm

Publisher's Note Springer Nature remains neutral with regard to jurisdictional claims in published maps and institutional affiliations. 